Fac. of Vet. Med., Tanta University, Kaff Ei Sheikh .

\title{
MORPHOLOGICAL AND HISTOCHEMICAL STUDIES ON THE TONGUE OF TILAPIA FISH (OREOCHROMIS NILOTICUS)
}

(With 19 Figures)

By

MONA A. ALI and A. HASAN

(Received at 27/6/2005)

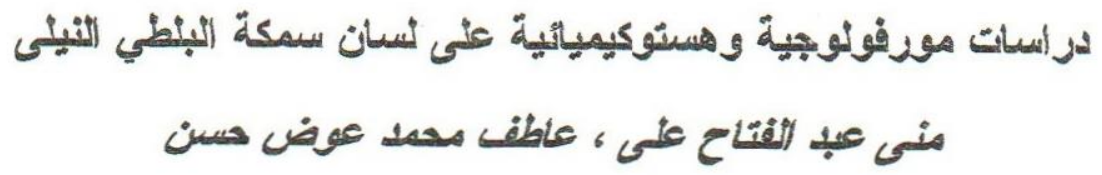

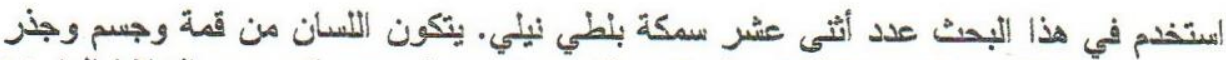

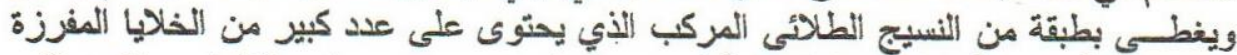

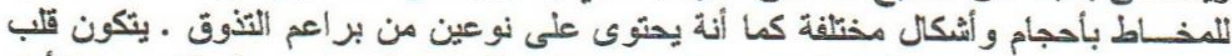

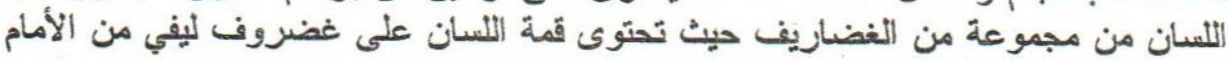

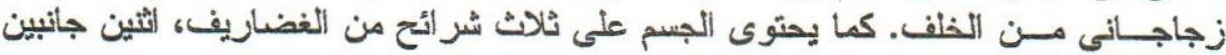
وواحدة علوية.

\section{SUMMARY}

The tongue of twelve mature fishes (O. niloticus) was subjected to gross morphological and scanning electron microscopical as well as light microscopical studies. Grossly, the tongue could be divided into apex, body and root. Scanning electron microscope showed that there were concentrically arranged fingerprint-like structures on the free surface of the uppermost cell layer of epithelium. Openings with different sizes were demonstrated on the surface of the tongue. It was found that the tongue was covered with stratified squamous nonkeratinized epithelium. The epithelium of the dorsal surface contained numerous large vacuolated mucus- secreting cells with different shapes and sizes. Few taste buds were observed within the epithelium of the dorsal surface of the tongue. The core of the apex contained a central plate of cartilage which was of the fibrous variety rostrally and hyaline type caudally. The core of the body contained three cartilaginous plates; two lateral plates of the hyaline type, which ossified caudally and a single dorso-median 
plate, which was formed of large rostral hyaline and small caudal fibroelastic parts.

Key words: Fish, Tilapia nilotica, tongue, histochemistry.

\section{INTRODUCTION}

The $O$. niloticus is the most important fresh water fish in the River Nile in Egypt. It is of a considerable economic importance, contributing about $32 \%$ of the total country catch (Gafrd, 1996). The tilapia live almost in shore water and feed mainly on periphytes and algae (Bishai and Khalil, 1997).

The tongue of animals and birds transports and swallows the food and plays an important role in the physiology of the mouth (Smith, et al., 1988). The knowledge about the tongue of the fish especially that of $O$. niloticus are meager in the available literature, therefore this study aimed to give more macroscopic and microscopic information about the tongue of the Nile tilapia (O. niloticus).

\section{MATERIALS and METHODS}

This study was carried out on 12 mature fishes (O. niloticus). Five fishes were used to demonstrate the gross morphological feature. The mouth cavity was opened, the tongues with the lower jaws were removed and fixed in 10\% formalin.

For scanning electron microscopy, specimens from three fishes were taken and fixed immediately in paraformaldehyde $2.5 \%$ and glutraldehyde $2.5 \%$ solution in $0.1 \mathrm{ml}$ phosphate buffer for 4 hours at $4^{\circ} \mathrm{C}$. After washing in the same buffer, the specimens were post-fixed in osmium tetroxide $1 \%$ in phosphate buffer for 2 hours followed by washing in the same buffer. The specimens were then dehydrated in ascending grades of ethanol followed by critical point draing in carbon dioxide, then sputter-coated with gold and examined with a JEOL5400LV scanning electron microscope.

For light microscopy, specimens were taken from four fishes. After fixation in Bouin's solution, the specimens were dehydrated, cleared and embedded in paraffin wax. Sections of 5-7 um thickness were cut. The sections were stained with H\&E, Periodic Acid Schiff (PAS), trichrome, alcian blue (Ab) at ph 2.5 and Weigerts elastic stains. (Bancroft and Stevens, 1996). 


\section{RESULTS}

\section{1- Morphological studies (Figs. 1, 2, 3, 4, 5):}

The tongue was a prismatic in shape and lodged in a shallow groove formed by the lower jaw (dental bones and floor of the mouth). It had two surfaces, dorsal and ventral. The dorsal surface was smooth and divided longitudinally by a central median ridge. It showed scattered pigmented spots which were numerous at the apex of the tongue. These spots appeared black by the naked eye. The ventral surface was also smooth and was connected to the mouth floor by a short frenulum.

Grossly, the tongue could be divided into apex, body and root. The apex was relatively short and have a pointed free part which showed numerous dark pigment spots. The body was relatively the wider part behind the apex, while the root was connected with the gill arches at an imaginary transverse level limiting the caudal boundary of the oral cavity ventrally.

The tongue of Tilapia niloticus was supported by several plates of cartilage. The apex was supported by a central cartilaginous plate. The body was supported by two lateral plates of cartilages, which represented the rostral end of the hyomandibular bone. A dorso-median cartilaginous plate supported the dorsum of the tongue.

\section{2- Scanning electron microscopy (Figs. 6, 7, 8):}

Scanning electron microscopy showed that there were concentrically arranged fingerprint-like structures on the free surface of the uppermost cell layer of epithelium of the tongue. Well developed microplicae were also seen on the surface of the cells. In addition, openings with different sizes were demonstrated on the surface of the tongue. Some openings showed secretion, while others did not. Taste buds could not be observed.

\section{3- Light microscopy:}

The tongue was covered with stratified squamous nonkeratinized epithelium. The epithelium of the dorsal surface was relatively thicker than that of the ventral one (Fig. 9\&10). The epithelium of the dorsal surface contained numerous large vacuolated mucus- secreting cells with different shapes and sizes (Fig. 11). These cells exhibited strong PAS+ve and $\mathrm{Ab}+\mathrm{ve}$ reaction (Figs. 12\&13). Few taste buds were observed in the epithelium of the dorsal surface of the tongue. According to the position of the taste buds, two types could be recognized, the first was embedded in the epithelium of the tongue (Fig. 11) and the second opened directly 
on the surface of the tongue (Fig.14). Structurally, the two types were similar. They were formed of a group of spindle-shaped cells with elongated, strongly basophilic nuclei, and long apical directed cytoplasmic processes. These cells were surrounded externally by the lining epithelium of the tongue and their apex showed homogenous acidophilic substance. The lamina propria was formed of a thin layer of longitudinally arranged collagen fibers followed by a layer of loose connective tissue containing pigment cells (Figs. 11\&12). The core of the apex contained a central plate of cartilage which was fibrocartilaginous in type rostrally and hyaline caudally (Figs. 15\&16). Also, the core of the body contained three cartilaginous plates; two lateral plats of hyaline type which, were ossified caudally (Figs. 17\&18), and a single dorso-median plate which was formed of two parts, a large rostral hyaline part and a small caudal fibro-elastic part (Fig. 19). Fat cells could be also demonstrated.

\section{DISCUSSION}

The current study revealed that Tilapia nilotica has a poorly developed tongue. It is prismatic in shape with a central median ridge, where other species as Gnathonemus petersii has a grooved tongue (Mikuriya, 1972), and many other species has no tongue at all (Harder, 1975). The tongue of Tilapia is formed of cartilaginous support and connective tissue elements covered with epithelium but neither intrinsic nor extrinsic muscles were observed in this study. In Polypteridae, there is a well developed tongue containing skeletal muscle called lissohyoglossus muscle (Marcus, 1934). Also Toxotes jaculator has a muscular tongue (Wegner, 1936). However, the tongue of Tilapia nilotica seams to be passively movable with the branchial arches (gills).

The Present study revealed that the surface of the epithelial cells was studded with numerous microplicae that were concentric, resembling finger prints. These findings were found also in the gill arch of the Tilapia (Ahmed \& Salma, 2004). In addition, these microplicae reflect their high secretory activity (Pinky et al., 2002). Our observations revealed that the epithelium of the dorsal surface of the tongue contains numerous mucus- secreting cells. Pinky et al. (2002) supposed that the mucus may lubricate the surface and protect the epithelia from abrasion. This mucous nature is important not only as a protective barrier (Laurent et al., 1985 and McCabon et al., 1987), but also has an ionoreguratory 
function (Handy et al., 1989). In addition, the mucos layer has been suggested to play a role in the feeding process by trapping particulate materials (Fryer and Iles, 1972 and Guinea and Fernandez, 1992). The mucous- secreting cells in our studies exhibited strong PAS+ve and $A b+v e$ reaction. According to Scocco et al. (2002), these cells are considered as seromucoid-secreting cells and the sites showed PAS+ve reaction is due to presence of glycoaminoglycans. These glycolconjugates could evolve or modify themselves following changes of physiological and environmental condition. There is also a specific defensive role of the mucosa related to glycol-conjugates (NieuwAmerongen et al., 1995). In the present study, Few taste buds were observed in the epithelium of the dorsal surface of the tongue. According to the position of the taste buds, two types could be recognized, the first was embedded in the epithelium of the tongue and the second opened directly on the surface of the tongue. According to Boudriat and Reutter (2001) who divided the taste buds of sighted river fish according to their position into three types: type I (elevated above the surrounding epithelium), type II (slightly elevated) and type III (not elevated or sunken). Moreover, Fishlson et al. (2004) added another $4^{\text {th }}$ type of taste buds that comprising very small buds on lips and oropharyngeal cavity of cardinal fish. We can conclude that the taste buds of the tongue in our study were of both type II and III. Taste buds may help the fish to locate and trigger a pick up reflex (Pinky et al., 2002), also they probably help in mechanoreception and chemoreception (Ray and Ray,1986). They added that SEM and light microscopical observations on the structure and distribution of taste buds in the oral cavity clearly revealed that the fish is purely a taste- feeder and scans and gropes the food materials from the bottom of the pond.

In this study, openings with different sizes were demonstrated with scanning microscopy and some openings showed secretion, while others did not. We can suppose that the large sized openings are of the mucus-secreting cells and the small sized openings are of taste buds.

\section{REFERENCES}

Ahmed E. Zayed and Salma A. Mohamed (2004): Morphological study on the gills of two species of fresh water fishes: Oreochromis niloticus and Clarias gariepinus. Ann. Anat. 186:295-304. 
Bancroft, J.D. and Stevens, A. (1996): Theory and Practice of Histological Techniques. Churchill Livingestone, Einberg,
London.

Bishai, H.M. and Khalil, M.T. (1997): Fresh water Fishes of Egypt. Publication of National Biodiversity Unit. No, 9.

Boudriat $F$. and Reutter $K$. (2001): Ultrastructure of the taste buds in the cave fish Astyanax jordani (Anoptichthys) and the sighted river fish Astyanax mexicanus (Teleostei, Characidae). J. Comp. Neurol.,2001, June , 11, 434(4) : 428-44.

Fishlson, L.; Delarea, Y. and Zverdling, A. (2004): Taste bud form and distribution on lips and in the oropharyngeal cavity of cardinal fish spesies (Apogonidea, Teleostei), with remarks on their dentition. J Morphol. 259(3): 316-327.

Fryer, G. and Iles, T.D.(1972): The Cichlid fishes of great lake of Africa. Neptune City, N.:T. F. H. Publication

Gafrd (general Authority of Fish Research Development in Egypt) (1996): Annual report for country fish production.

Guinea, J. and Fernandez, F. (1992): Morphological and biometrical study of the gill rakers in four species of mullet. J., Fish Biol. 41: 381-397.

Harder, W. (1975): Anatomy of Fishes. E Schweizer bart'sche Verlags. Buchhandlung (Naegele U. Obermiller) Stuttgart.

Handy, R.D.; Eddy, F.B. and Romain, G. (1989): In vitro evidences for the ionoregulatory role of rainbow trout mucus in acid, acid/aluminum and zinc toxicity. J Fish Biol. 35:737-747.

Laurent, P.; Hobe, H. and Dunel-Erb, S. (1985): The role of environmental salmonid fish. Cell Tissue Res. 240: 672-692.

Marcus, H. (1934): Zur Stammesgeschichte der Zunge. II Ueber die musculature der Polypterus zunge. Anat. Anz., 77: 357-362.

McCabon, C.P.; Pascoe, D. and Kavanagh, M. (1987): Histochemical observations on the Salmonid Salmosalar L., and Salmotruta L., and the ephemeropterans Baetis rhodani (Pict.) and Ecdtonurus venosus (Fabr.) following a simulated episode of acidity in an upland stream. Hydrobiologie 153: 3-12.

Mikuriya, B.A. (1972): The gross anatomy and microscopic anatomy of the tongue and lower jaw of Gnathonemus petersii (Gthr. 1862) (Mormyridae, Teleostei). ZA. Morph. Tiere, 73: 195-208. 
Nieuw-Amerongen, A.V.; Bolscher, J.G.M. and Veerman, E.C.I. (1995): Salivary mucins: protect relation yo their diversity. Glycobiology 5: 733- 740 .

Pinky, Mitta S.; Ojha, J. and Mittal, A. (2002): Scanning electron microscopic study of the structures associated with lips of an Indian hill stream fish Garra lamata (Cyprinidae, Cypriniformes). Eur. J. Morphol. Vol. 40 (3): 161-169.

Ray, A. and Ray, A.K. (1986): Functional scanning electron microscopical observations on the oral roof in an air- breathing teleost, Clarias batrachus (LINN.). Gegenbaurs Morphol. Jahrb. 132: (3): 429-441.

Scocco, p.; Fgioli, O.; Cecarelli, P. and Pedini, V. (2002): From conventional to modern histochemistry: way for the fine characterization of secretion glycoconjugates. Embryol. 107; 3 : 43-54.

Smith, D.E.; Paterson, C.; Scratcherd, T. and Read, N.W. (1988): Textbook of Physiology. Churchill Livingstone, Einberg, London. 11 Ed. 234.

Wegner, I. (1936): Ueber den Schutzenfisch, Toxotes jaculator pall- B1. Aquarien-U. Terrarien K de. 47: 169- 174.

\section{FIGURES}

Figs. 1\&2: Stereomicrograph of the tongue showing the morphological features. A: apex; B: body; R: root and F: oral floor and M: median ridge. (1: dorsal view $\mathrm{x}: 9$ \& 2 : lateral view $\mathrm{x}: 9)$

Figs. 3, 4\&5: Stereomicrograph of the tongue showing the general structure. LC: lateral cartilage; DC: dorsal cartilage; CT: connective tissue; Ep: epithelium; F: floor of the mouth; $\mathrm{m}$ : muscle of the oral floor; fc: fibro-cartilage; b; bone; d: dorsal surface; v: ventral surface; g: gill arches and L: lip (3: parafin cross section in the apex; $\mathrm{x}: 30,4$ : cross section in the body; $\mathrm{x}: 25$ and 5: longitudinal section; $\mathrm{x}: 9$. Stain: $\mathrm{H \& E}$ ).

Figs. 6, 7\&8: Scanning electron micrographs of the dorsum of the tongue showing fingerprint-like structures (arrow); micro-ridges (double arrows); openings with different sizes (arrow heads) and s: secretion. 
Fig, 9: Longitudinal section at the apex of the tongue showing: d: dorsal surface; v: ventral surface; m: muscie of the oral floor; fc: fibrocartilage; hc: hyaline cartilage; $c$ : collagen fibers; $F$ : floor of the mouth (Stain: H\&E. x: 40).

Fig. 10: Cross section at the apex of the tongue showing: d: dorsal epithelium; v: ventral epithelium; fc: fibro-cartilage; c: collagen fibers (Stain H\&E X100).

Fig. 11: Section at the dorsal surface of the tongue showing; mucussecreting cells (arrows); T: taste buds ; c: collagen fibers and pigment cell (double arrows).( Stain H\&E X 400).

Fig. 12: Section at the apex of the tongue showing the PAS +ve reaction in the mucus- secreting cells (arrows) and in the fibro-cartilagous plate (double arrows). (Stain: PAS X 100).

Fig. 13: Section at the dorsal surface of the tongue showing $A b+v e$ reaction in the mucus- secreting cells within the surface epithelium of the tongue (arrows). (Stain: $\mathrm{Ab} \mathrm{pH} \mathrm{2.5.} \mathrm{X1000).}$

Fig. 14: Section at the dorsal surface of the tongue showing: mucussecreting cells within the surface epithelium (arrows); $\mathrm{T}$ : taste bud, c: collagen fibers. (Stain: H\&E. X 1000).

Fig. 15: Section at the apex of the tongue showing: fc: fibro-cartilage; hc: hyaline cartilage; c: collagen fibers. (Stain: trichrome. X 40).

Fig. 16: Section at the apex of the tongue showing: fc: fibro-cartilage. (Stain: H\&E. X 100).

Figs. 17\&18: Section at the body and root of the tongue showing: B: body; R: root; hc: hyaline cartilage; b: bone.(17: longitudinal \&18:cross sections. Stain: H\&E. X 40).

Fig. 19: Section at the body of the tongue showing: DC: the dorsomedian plate of cartilage; fe: fibro elastic-cartilage; hc: hyaline cartilage. (Stain: weigert's elastic. X 100). 
Assiut Vet. Med. J. Vol. 51 No. 106 July 2005
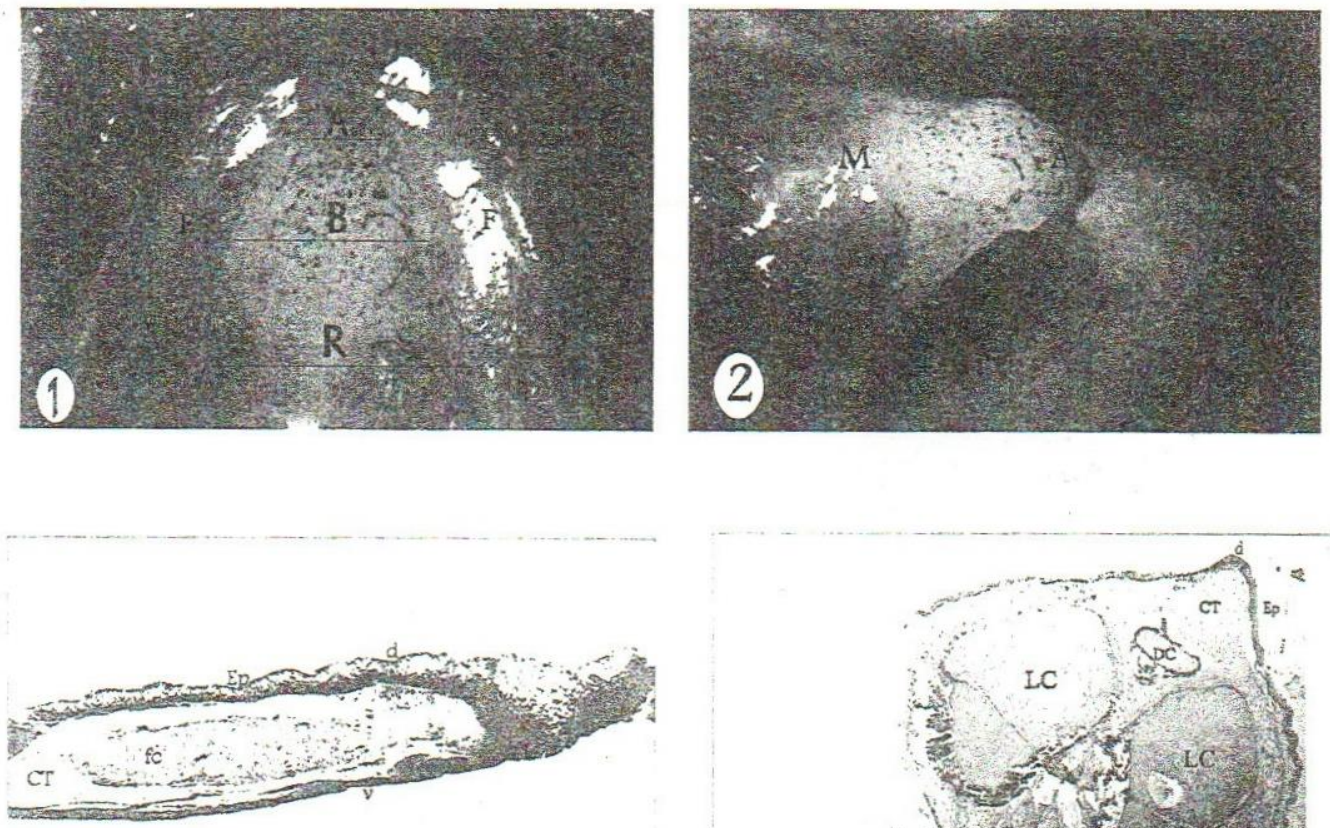

3
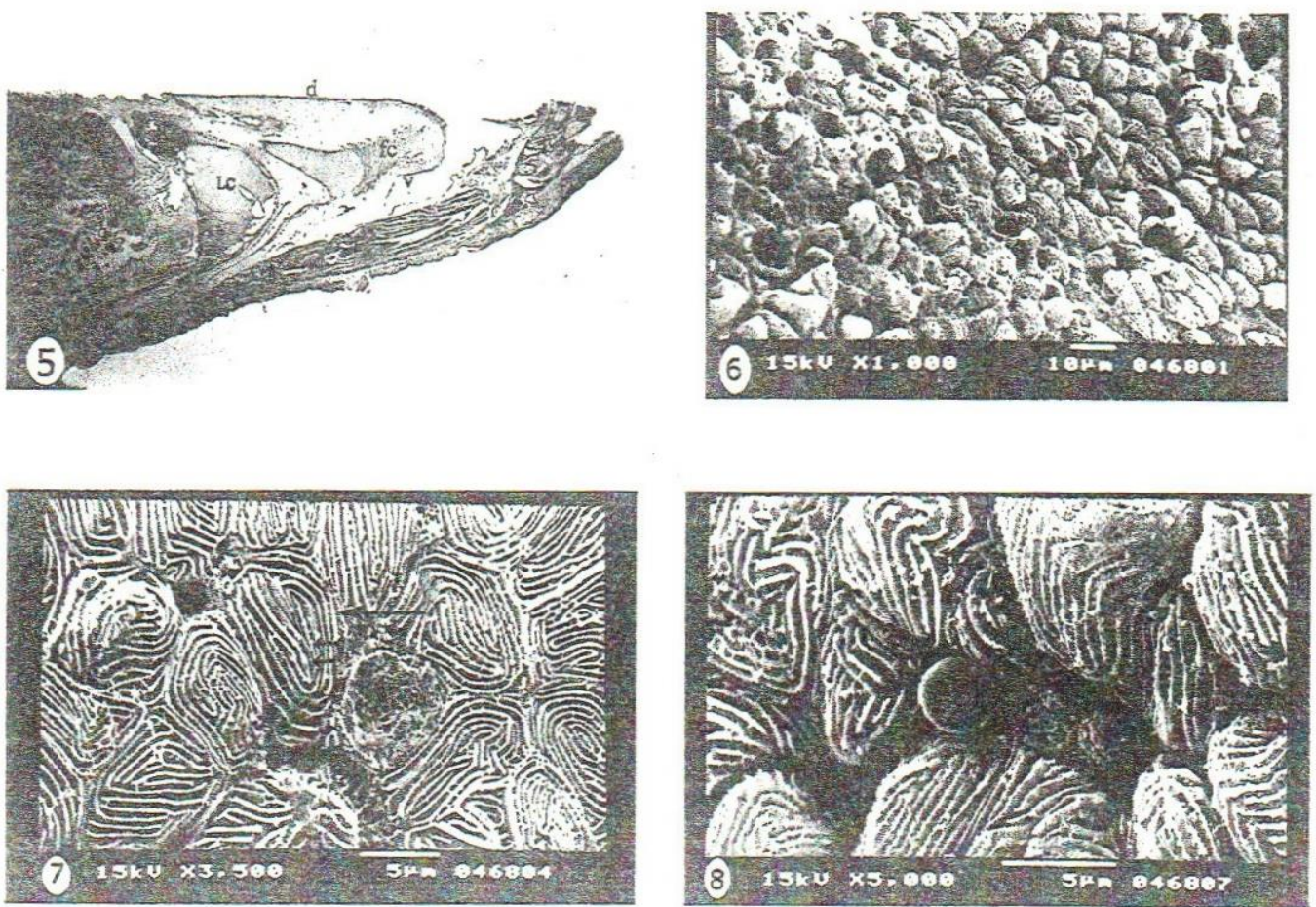

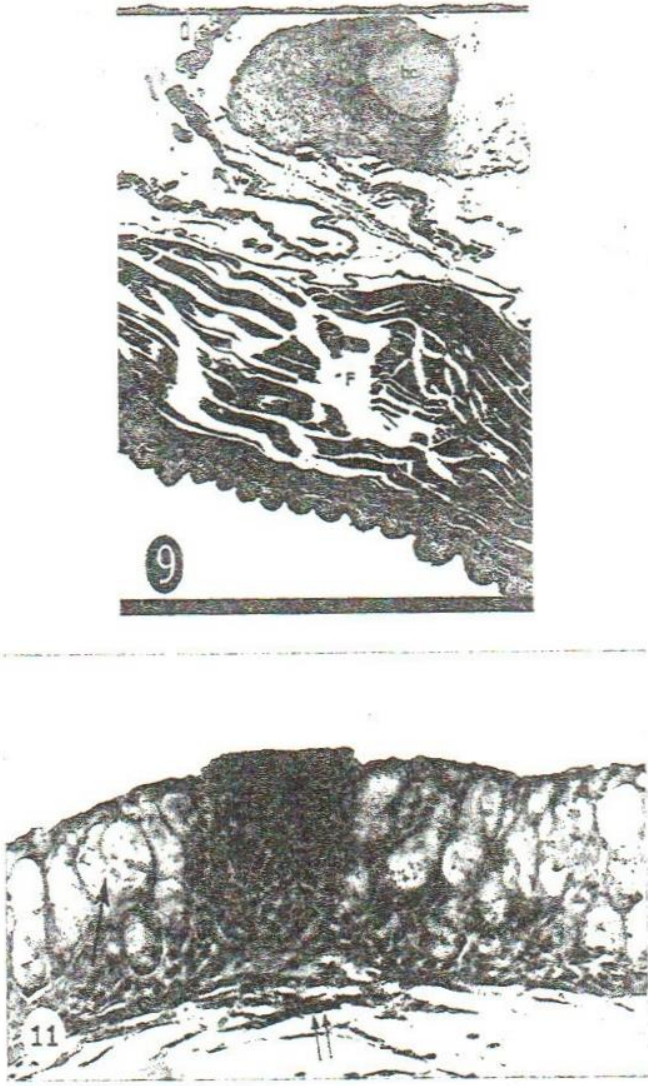

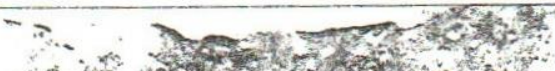

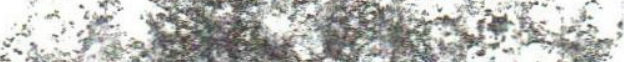

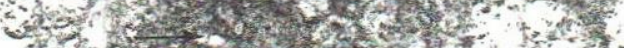

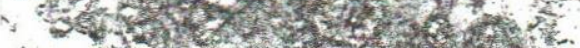

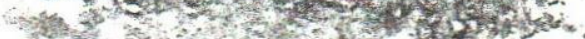

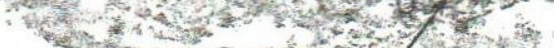

$\therefore 7,3$.

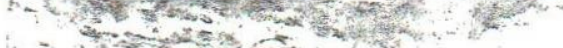

.

$13-100$

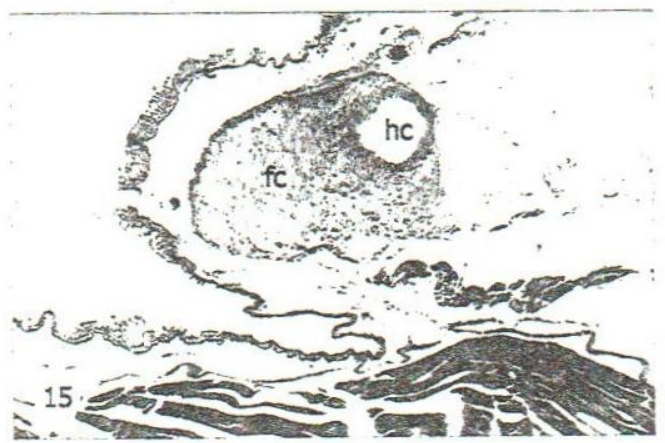

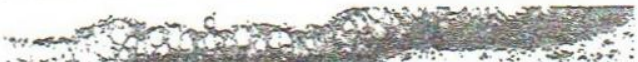
bet

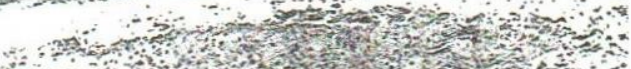

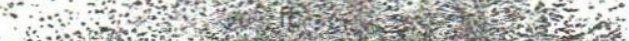

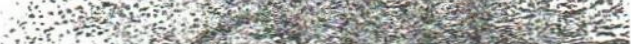

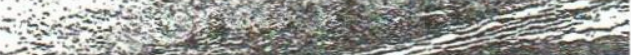
건

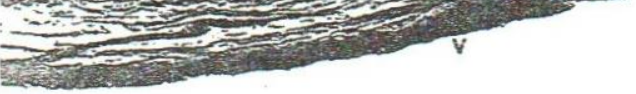

10
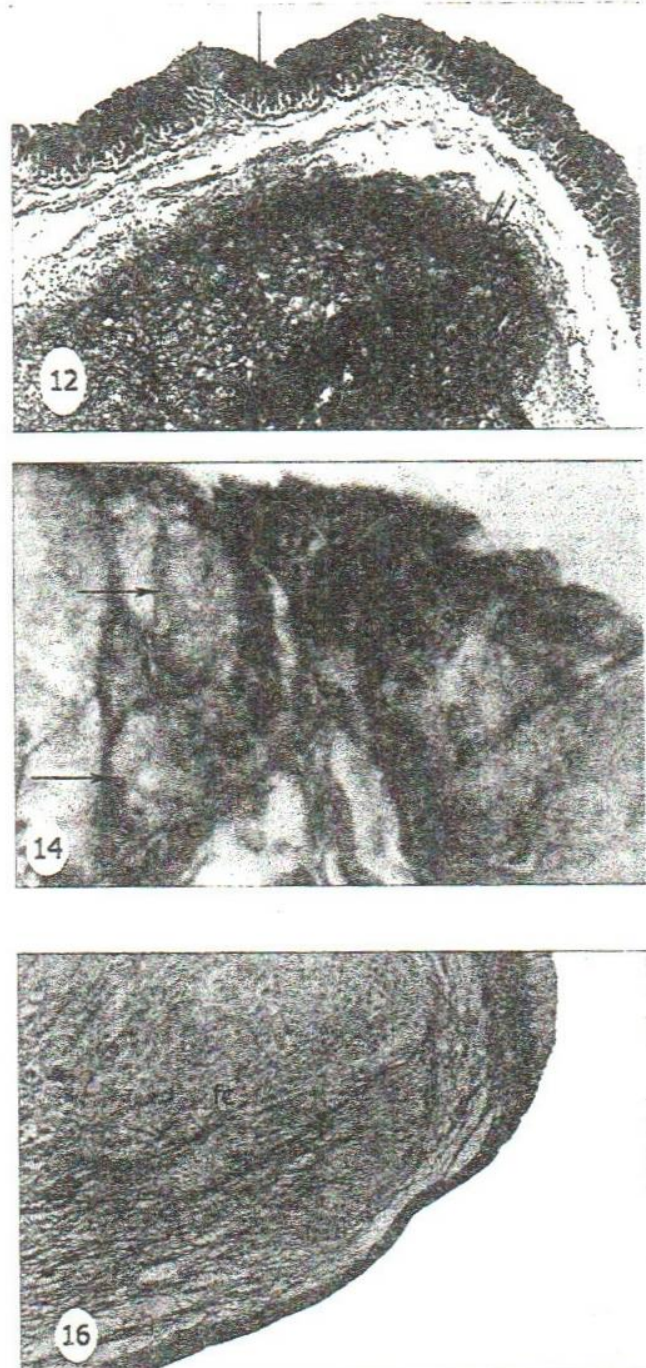

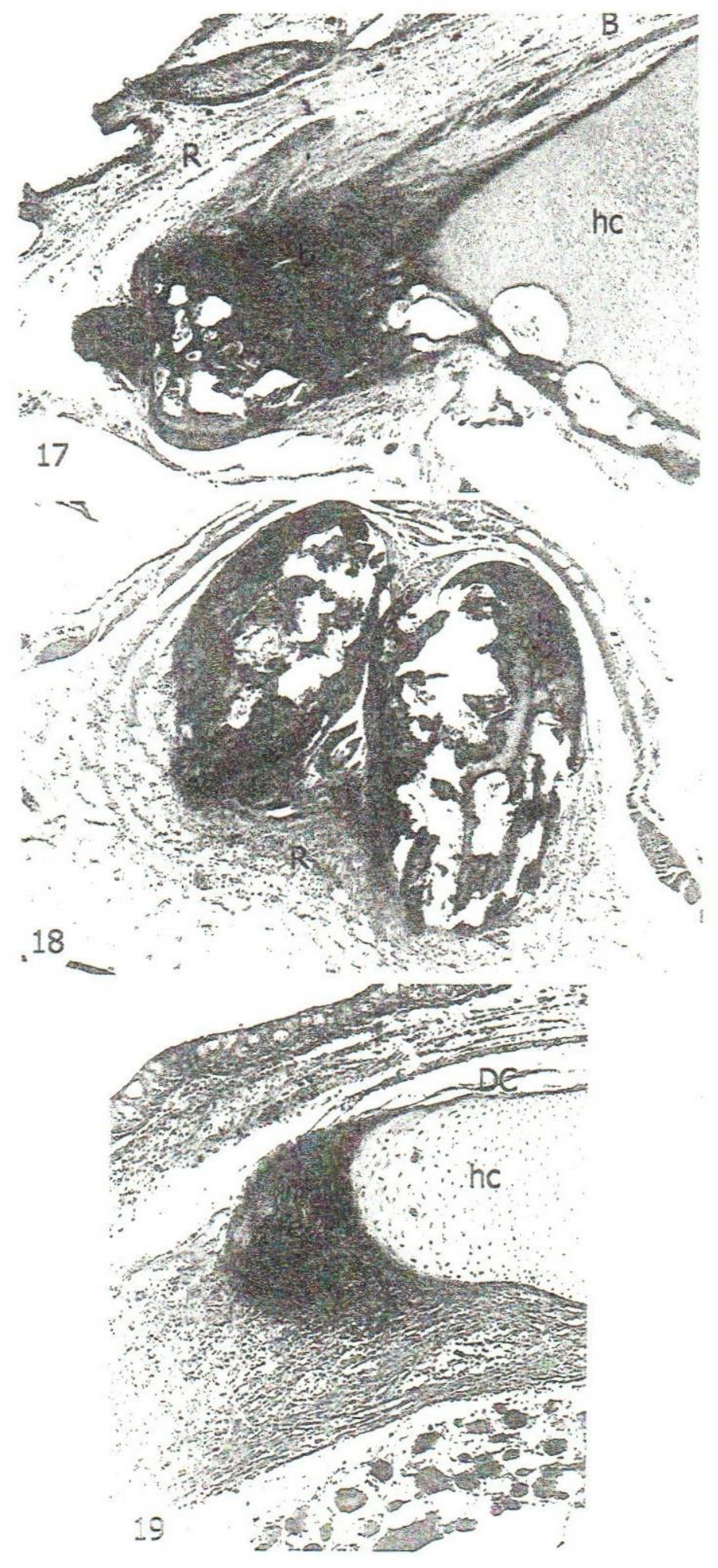